\title{
PENGARUH KOMITMEN PROFESIONAL, PERSONAL COST, DAN MORAL REASONING TERHADAP NIAT SESEORANG UNTUK MELAKUKAN TINDAKAN WHISTLEBLOWING
}

\author{
Wahyu Refky Prayogi, Dwi Suprajitno \\ Sekolah Tinggi Ilmu Ekonomi Putra Bangsa
}

\section{wahyurefkyprayogi@gmail.com}

\begin{abstract}
Abstrak
Penelitian ini bertujuan untuk menguji pengaruh Komitmen Profesional, Personal Cost dan Moral Reasoning terhadap niat untuk melakukan tindakan Whistleblowing dan ingin membuktikan bahwa Komitmen Profesional, Personal Cost dan Moral Reasoningberpengaruh terhadap niat untuk melakukan tindakan Whistleblowing. Model analisis data yang digunakan dalam penelitian ini adalah Analisis Regresi Linear Berganda.Sampel dalam penelitian ini ditentukan menggunakan metode purposive random sampling dengan kriteria responden adalah pegawai Kantor Pelayanan Pajak (KPP) Pratama Kebumen yang sudah bekerja minimal selama satu tahun atau lebih. Sampel dalam penelitian ini yaitu sebanyak 48 pegawai. Hasil analisis yang telah dilakukan dari penelitian ini menunjukan bahwa Komitmen Profesional berpengaruh positif dan signifikan terhadap niat untuk melakukan tindakan Whistleblowing pegawai Kantor Pelayanan Pajak (KPP) Pratama Kebumen, sedangkan Personal Cost dan Moral Reasoning tidak berpengaruh terhadap niat untuk melakukan tindakan Whistleblowing pegawai Kantor Pelayanan Pajak (KPP) Pratama Kebumen.

Kata kunci: Whistleblowing, Komitmen Profesional, Personal Cost, Moral Reasoning

\section{Abstract}

This study aimed to examine the effect of Professional Commitment, Personal Cost and Moral Reasoning on a person's intention to take Whistleblowing action and want to prove that Professional Commitment, Personal Cost and Moral Reasoning affect on a person's intention to take Whistleblowing action. The data analysis model used in this study was Multiple Linear Regression Analysis. The sample in this study was determined using purposive random sampling method with the criteria of respondents being employees of the Kantor Pelayanan Pajak (KPP) Pratama Kebumen who had worked for at least one year or more. The sample in this study were 48 employees. The results of the analysis carried out from this study indicated that Professional Commitment had a positive and significant effect on the intention to take action Whistleblowing employees of the Kantor Pelayanan Pajak (KPP) Pratama Kebumen, while the Personal Cost and Moral Reasoning did not affect the intention to take action Whistleblowing employees of the Kantor Pelayanan Pajak (KPP) Pratama Kebumen.
\end{abstract}

Keywords: Whistleblowing, Komitmen Profesional, Personal Cost, Moral Reasonin.

\section{PENDAHULUAN}

Kecurangan atau fraud merupakan halbanyak terjadi di sektor swasta maupun publik. Kecurangan (fraud) dapat dianggap sebagai masalah sosial-ekonomi yang serius karena besarnya dampak kerugian yang ditimbulkan dari tindakan ini. Di Indonesia banyak kasus-kasus kecurangan yang sering terjadi, salah satunya adalah korupsi. Kasus korupsi di Indonesia seolah sudah menjadi hal yang wajar, dimulai dari sebelum dan sesudah kemerdekaan, di era Orde Lama, Orde Baru, berlanjut hingga era Reformasi. Menurut Prasetyo (2016:8) korupsi adalah sesuatu yang busuk, jahat, dan merusak, berdasarkan kenyataan tersebut perbuatan korupsi menyangkut: sesuatu yang bersifat amoral, sifat dan keadaan yang busuk, menyangkut jabatan instansi, penyelewengan kekuasaan dalam jabatan karena pemberian, menyangkut faktor ekonomi dan politik serta penempatan keluarga atau golongan ke dalam kedinasan di bawah kekuasaan jabatan. Melihat dari berbagai kasus korupsi yang terjadi di Indonesia, strategi pemberantasan korupsi dapat dilakukan melalui pencegahan, pendeteksian, hingga penuntutan. Salah satu cara yang dapat dilakukan adalah dengan cara mengimplementasikan Whistleblowing System sehingga setiap pegawai berkesempatan untuk 
melaporkan tindakan koruptif ataupun pelanggaran lainnya yang dilakukan oleh rekan kerjanya namun pelapor akan mendapatkan perlindungan.

Whistleblowers akan menjadi peran yang sangat penting dalam membuka dan mengungkap perilaku tidak etis di instansi pemerintah ataupun swasta. Salah satu lembaga di Indonesia yang telah menerapkan peraturan mengenai Whistleblowing System adalah Lembaga Pengadaan Barang/Jasa Pemerintah (LKPP) yang berkedudukan sebagai Lembaga Pemerintah Non Kementrian (LPNK) dan bertanggung jawab langsung kepada presiden RI. Sistem tersebut tertuang dalam peraturan kepala LKPP Nomor : 7 Tahun 2012 tentang Whistleblowing System dalam pengadaan Barang/Jasa Pemerintah. Menurut laporan Association of Certified Fraud Examiner (ACFE), sekitar setengah dari kasus kecurangan (fraud) terungkap karena laporan dari whistleblowers. Hanya sekitar seperempat dari kasus fraud terungkap karena internal audit, dan seperempatnya lagi terungkap oleh adanya proses internal kontrol atau bahkan secara tidak sengaja (Tjahjono, 2013) dalam Ahyaruddin (2017).

Whistleblowers memiliki peran yang penting dalam mengungkap kecurangan yang terjadi dalam organisasi sehingga bisa mencegah kerugian bagi sejumlah besar pemangku kepentingan (stakeholders). Oleh karena itu, pemahaman yang lebih baik terkait dengan faktor-faktor yang yang berkaitan dengan whistleblowing dan bagaimana bisa mengungkapkan kecurangan adalah topik penting untuk diteliti.

Miceli dan Near (1988) dalam Kreshastuti, (2014) menyatakan bahwa, orang yang cenderung melakukan whistleblowing adalah orang yang menduduki jabatan profesional, memiliki reaksi positif terhadap pekerjaannya, lebih lama melayani (lama bekerja, usia, dan jumlah tahun sampai saat pensiun), mempunyai kinerja baik, laki-laki, mempunyai kelompok kerja yang lebih besar dan mendapatkan 'tanggung jawab' dari yang lain untuk menyatakan whistleblowing.

Berdasarkan uraian diatas penelitian ini bertujuan untuk mengetahui pengaruh komitmen profesional, personal cost, dan moral reasoning terhadap niat untuk melakukan tindakan whistleblowing pada pegawai KPP Pratama Kebumen.

\section{TINJAUAN PUSTAKA}

\section{Whistleblowing}

Menurut Near dan Miceli (1985) dalam Ahyaruddin (2017) whistleblowing merupakan pengungkapan atau pelaporan oleh anggota organisasi (anggota yang masih berada dalam organisasi maupun yang sudah keluar dari organisasi) terkait dengan praktik ilegal, tidak bermoral atau praktik yang tidak dapat dilegitimasi secara hukum dibawah kontrol majikan mereka, kepada orang ataupun organisasi yang mungkin mampu untuk mempengaruhi suatu tindakan.

Near et al (2008) dalam Hanif dan Odiatama (2017) menjelaskan bahwa ada tiga elemen yang terlibat dalam proses whistleblowing yaitu adanya orang yang melakukan pelaporan (whistleblower), adanya pengaduan mengenai terjadinya tindakan atau perbuatan yang tidak sesuai etika, umumnya sebuah organisasi atau kelompok yang terdiri dari kumpulan individu-individu yang berkomitmen melakukan tindakan pelanggaran atau tidak sesuai etika, dan adanya pihak-pihak yang menerima pelaporan atau pengaduan whistleblowing tersebut.

Menurut Brandon (2013) terdapat dua tipe whistleblower, yaitu: Whistleblowing internal terjadi ketika seseorang atau beberapa orang karyawan mengetahui kecurangan yang dilakukan oleh karyawan lain atau kepala bagiannya, kemudian melaporkan kecurangan itu kepada pimpinan perusahaan yang lebih tinggi. Whistleblowing eksternal Whistleblowing eksternal menyangkut kasus di mana seorang pekerja atau karyawan mengetahui kecurangan yang dilakukan perusahaannya lalu membocorkan kepada masyarakat karena dia tahu bahwa kecurangan itu akan merugikan masyarakat.

\section{Hubungan Komitmen Profesional dan Whistleblowing}

Karir merupakan hal besar dan juga merupakan bagian utama dalam kehidupan seseorang dan komitmen profesional memiliki implikasi penting terhadap hal tersebut baik pada level individual ataupun organisasi. Komitmen profesional dikaitkan dengan meningkatnya kinerja, turunnya niat untuk pindah kerja, serta kepuasan kerja yang lebih besar (Meixner dan Bline, 1989) dalam (Merdikawati, 2012). Komitmen Profesional juga dapat dikaitkan dengan etika dan niat whistleblowing. Seorang yang berkomitmen profesi yang tinggi akan memercayai dan menerima tujuan profesi serta berkeinginan untuk melakukan berbagai upaya demi mencapai tujuan profesi tanpa diminta. Aranya et al. (1982) dalam Pangesti dan Rahayu (2017) juga berpendapat bahwa komitmen profesional yang lebih tinggi harus di refleksikan di dalam kepekaan yang lebih kuat terhadap masalah-masalah mengenai etika profesi.

Komitmen Profesional menuntut seseorang untuk menjunjung tinggi nilai-nilai dan norma-norma yang ada sesuai dengan standar profesional dan etika profesi yang berlaku, sehingga seorang akuntan atau auditor harus bertindak secara profesional sesuai dengan tujuan dan nilai-nilai organisasi atau profesinya. Seorang akuntan atau auditor yang menjunjung tinggi komitmen terhadap profesionalismenya akan melakukan pencegahan dalam bersikap yang tidak sesuai dengan standar profesional dan etika profesi yang berlaku.

Pengaruh Komitmen Profesional terhadap niat untuk melakukan tindakan Whistleblowing ini dapat dibuktikan dalam penelitian Nugraha (2017) yang menunjukan bahwa dengan adanya Komitmen Profesional dalam diri seorang auditor dapat membantu mengungkapkan kecurangan yang terjadi dalam suatu perusahaan. Berdasarkan hasil penelitian terdahulu, maka hipotesis yang diajukan dalam penelitian ini: 
$\mathbf{H}_{1}$ : Komitmen Profesional berpengaruh positif terhadap niat untuk melakukan tindakan Whistleblowing

\section{Hubungan Personal Cost dan Whistleblowing}

Schutlz et al (1993) dalam Ramadhany (2017) mengartikan Personal Cost of Reporting adalah pandangan pegawai terhadap risiko pembalasan atau balas dendam atau sanksi dari anggota organisasi yang dapat mengurangi minat pegawai untuk melaporkan wrongdoing.

Personal Cost merupakan salah satu alasan utama yang menyebabkanseseorang tidak ingin melaporkan dugaan pelanggaran karena mereka meyakinibahwa mereka akan mengalami retaliasi. Retaliasi atau tindakan balas dendam adalahsebuah perilaku yang ditujukan untuk mengembalikan tindakan yang pernahdilakukan seseorang.

Pengaruh Personal Cost terhadap niat untuk melakukan tindakan Whistleblowing ini dapat dibuktikan dalam penelitian Lestari dan Yaya (2017) yang menyebutkan bahwa personal cost berpengaruh signifikan negatif terhadap niat melaksanakan tindakan whistleblowing. Berdasarkan hasil penelitian terdahulu, maka hipotesis yang diajukan dalam penelitian ini:

$\mathbf{H}_{2}$ : Personal Cost berpengaruh negatif terhadap niat untuk melakukan tindakan Whistleblowing

\section{Hubungan Moral Reasoning dan Whistleblowing}

Moral adalah sikap mental dan emosional yang dimiliki oleh individu sebagai anggota kelompok sosial dalam melakukan tugas-tugas serta loyalitas pada kelompok (Falah, 2006) dalam (Al-Fithrie, 2015). Menurut Kohlberg (1969) dalam Diani dan Narsa (2017) Dasar utama untuk mengetahui kecenderungan individu dalam melakukan suatu tindakan tertentu, khususnya terkait dilema etika, adalah melalui level penalaran moral seseorang.

Seseorang dengan tingkat Moral Reasoning tinggi dalam memberikan Persepsi Etis dari kasus pelanggaran etika akan mendasarkan perilaku akuntan tersebut pada prinsip-prinsip moral. Sebaliknya, seseorang dengan tingkat Moral Reasoning rendah cenderung mengabaikan prinsip-prinsip moral dalam memberikan Persepsi Etis atas kasus pelanggaran etika. Seseorang dengan tingkat Moral Reasoning tinggi akan memiliki persepsi positif kepada akuntan yang mematuhi kode etik profesi akuntan dan akan memiliki persepsi negatif kepada akuntan yang melanggar kode etik profesi, sedangkan seseorang dengan tingkat Moral Reasoning rendah cenderung akan meniru perilaku akuntan yang melanggar kode etik profesi akuntan.

Pengaruh Moral Reasoning terhadap niat untuk melakukan tindakan Whistleblowing ini dapat dibuktikan dalam penelitian Ahyaruddin dan Asnawi (2017) yang menunjukkan bahwa tingkat moral individu tidak memiliki pengaruh terhadap kecenderungan untuk melakukan whistleblowing.
Berdasarkan hasil penelitian terdahulu, maka hipotesis yang diajukan dalam penelitian ini:

$\mathbf{H}_{3}$ : Moral Reasoning berpengaruh positif terhadap niat untuk melakukan tindakan Whistleblowing

$\mathbf{H}_{4}$ : Komitmen Profesional, Personal Cost, dan Moral Reasoning secara simultan berpengaruh positif terhadap niat untuk melakukan tindakan Whistleblowing

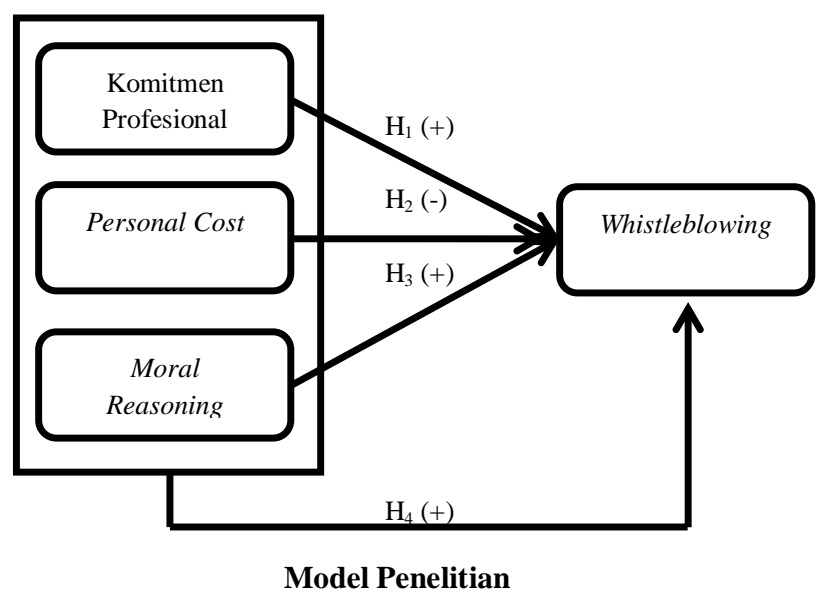

\section{METODE PENELITIAN}

\section{Sampel dan Data}

Teknik pengambilan sampel yang digunakan dalam penelitian ini adalah metode purposive random sampling, yaitu dengan melakukan pengambilan sampel dari populasi berdasarkan suatu pertimbangan (judgement) dan kriteria tertentu (Prasasti, 2017). Kriteria pemilihan sampel dalam penelitian ini yaitu pegawai Kantor Pelayanan Pajak Pratama Kebumen yang sudah bekerja selama satu tahun atau lebih, dengan pertimbangan bahwa mereka telah mengenal lebih baik dan memiliki ikatan emosi dengan sesama rekan akuntan maupun atasan.

Berdasarkan jenis data dan metode analisis data yang digunakan, penelitian ini termasuk dalam jenis penelitian kuantitatif. Menurut Sugiyono (2010:8) metode penelitian kuantitatif dapat diartikan sebagai metode penelitian yang berlandaskan pada filsafat positivisme, digunakan untuk meneliti pada populasi atau sempel tertentu, pengumpulan data menggunakan instrumen penelitian, analisis data bersifat kuantitatif/statistik, dengan tujuan untuk menguji hipotesis yang telah ditetapkan. Data kuantitatif adalah data yang dapat diukur sehingga dapat menggunakan statistik dalam pengujiannya (Kountur, 2004:16).

Metode pengumpulan data yang digunakan dalam penelitian ini adalah dengan membagikan kuesioner yang akan diisi atau dijawab oleh setiap responden. Daftar pertanyaan atau pernyataan dalam kuesioner penelitian ini berupa pertanyaan atau pernyataan tertutup karena alternatif-alternatif jawaban telah disediakan. Kuesioner yang digunakan berfungsi untuk mengukur pendapat, sikap, dan pengetahuan responden mengenai tindakan whistleblowing yang berkaitan dengan pengaruh beberapa faktor antara lain komitmen profesional, personal cost, dan moral reasoning. 


\section{Pengukuran Variabel}

Pengukuran variabel whistleblowing mengadopsi instrumen skenario kasus yang dikembangkan oleh (Schultz, 1993). Skenario ini juga pernah digunakan oleh (Malik, 2010) yang menggunakan dua aspek dari whistleblowing yaitu tentang pandangan mengenai persepsi whistleblowing dan whistleblowing itention.

Pengukuran variabel komitmen profesional mengadopsi instrumen kuesioner yang telah dikembangkan oleh Dwyer et al (2000). Instrumen kuesioner ini juga pernah digunakan oleh (Yulianto, 2015).

Pengukuran variabel personal cost mengembangkan instrumen kuesioner yang pernah digunakan oleh (Ramadhany, 2017). Pengukuran variabel moral reasoning mengadopsi instrumen kuesioner yang telah dikembangkan oleh Cohen et al (2001). Instrumen kuesioner ini juga pernah digunakan oleh (Al-Fithrie, 2015). Intrumen berupa kuesioner diukur dengan menggunakan skala likert 5 point.

\section{HASIL PENELITIAN}

\section{Uji Validitas dan Reliabelitas}

Hasil uji validitas dan reliabelitas menunjukkan bahwa instrumen penelitian sudah valid dan reliabel dapat dilihat pada tabel 1 dan tabel 2.

Hasil pada tabel 1, diketahui bahwa corrected item-total correlation menunjukkan angka > 0,2403 untuk setiap indikator, hal ini berarti bahwa minimal uji validitas telah terpenuhi. Uji reliabelitas mensyaratkan cronbach's alfa $>0,7$, pada tabel 2 dapat dilihat bahwa semua indikator sudah reliabel.

Tabel 1 Uji Validitas

\begin{tabular}{ccc}
$\begin{array}{c}\text { No. Butir } \\
\text { Pertanyaan }\end{array}$ & $\begin{array}{c}\text { Correlated } \\
\text { item }- \text { Total } \\
\text { Corelation }\end{array}$ & R tabel \\
\hline 1 (KP1) & 0,571 & 0,2403 \\
2 (KP2) & 0,329 & 0,2403 \\
3 (KP3) & 0,397 & 0,2403 \\
4 (KP4) & 0,596 & 0,2403 \\
5 (KP5) & 0,535 & 0,2403 \\
6 (KP6) & 0,371 & 0,2403 \\
1 (PC1) & 0,589 & 0,2403 \\
2 (PC2) & 0,335 & 0,2403 \\
3 (PC3) & 0,702 & 0,2403 \\
4 (PC4) & 0,720 & 0,2403 \\
5 (PC5) & 0,549 & 0,2403 \\
6 (PC6) & 0,633 & 0,2403 \\
7 (PC7) & 0,718 & 0,2403 \\
8 (PC8) & 0,430 & 0,2403 \\
9 (PC9) & 0,586 & 0,2403 \\
10 (PC10) & 0,561 & 0,2403 \\
1 (MR1) & 0,400 & 0,2403 \\
2 (MR2) & 0,370 & 0,2403
\end{tabular}

$\begin{array}{ccc}3 \text { (MR3) } & 0,506 & 0,2403 \\ 4 \text { (MR4) } & 0,399 & 0,2403 \\ 5 \text { (MR5) } & 0,430 & 0,2403 \\ 6 \text { (MR6) } & 0,382 & 0,2403 \\ 7 \text { (MR7) } & 0,556 & 0,2403 \\ 8 \text { (MR8) } & 0,268 & 0,2403 \\ 9 \text { (MR9) } & 0,560 & 0,2403 \\ 10 \text { (MR10) } & 0,373 & 0,2403 \\ 11 \text { (MR11) } & 0,342 & 0,2403 \\ 12 \text { (MR12) } & 0,304 & 0,2403 \\ 1 \text { (WB1) } & 0,755 & 0,2403 \\ 2 \text { (WB2) } & 0,467 & 0,2403 \\ 3 \text { (WB3) } & 0,596 & 0,2403 \\ 4 \text { (WB4) } & 0,718 & 0,2403 \\ 5 \text { (WB5) } & 0,569 & 0,2403 \\ 6 \text { (WB6) } & 0,495 & 0,2403 \\ 7 \text { (WB7) } & 0,349 & 0,2403 \\ 8 \text { (WB8) } & 0,402 & 0,2403\end{array}$

Tabel 2 Uji Reliabelitas

\begin{tabular}{ccc} 
Variabel & $\begin{array}{l}\text { Cronbach's } \\
\text { Alpha }\end{array}$ & Keterangan \\
\hline $\begin{array}{c}\text { Komitmen } \\
\text { Profesional }\end{array}$ & 0,729 & Reliabel \\
\hline Personal Cost & 0,862 & Reliabel \\
\hline $\begin{array}{c}\text { Moral } \\
\text { Reasoning }\end{array}$ & 0,765 & Reliabel \\
\hline Whistleblowing & 0,823 & Reliabel
\end{tabular}

\section{Pengujian Hipotesis}

Pengujian hipotesis dalam penelitian ini dilakukan dengan menggunakan software SPSS, dengan pengujian asumsi klasik dilakukan sebelumya. Pengujian hipotesis dilakukan emnggunakan analisis regresi linear berganda. Hasil pengujian dapat dilihat pada tabel berikut:

\section{Tabel 3 Ringkasan Pengujian Hipotesis}

\begin{tabular}{lllll}
\hline Keterangan & $\mathbf{B}$ & $\mathbf{t}$ & Sig & Kesimpulan \\
\hline (constant) & 14,759 & 3,069 & 0,004 & \\
\hline KP & 0,989 & 5,867 & 0,000 & Diterima \\
\hline PC & 0,037 & 0,488 & 0,628 & Ditolak \\
\hline MR & $-0,138$ & -1.721 & 0,092 & Ditolak \\
\hline
\end{tabular}

Hipotesis pertama yang diajukan dalam penelitian ini adalah Komitmen Profesional berpengaruh positif terhadap niat untuk melakukan tindakan Whistleblowing.Berdasarkan hasil analisis dari uji $\mathrm{t}$ pada variabel komitmen profesional, menunjukkan bahwa probabilitas signifikansi untuk variabel komitmen profesional (X1) sebesar 0,000< 0,05 dan hasil perhitungan diperoleh angka $t_{\text {hitung }}$ sebesar 5,867 > $t_{\text {table }}$ sebesar 1,68023. Maka dapat disimpulkan bahwa hipotesis pertama diterima. 
Hipotesis kedua yang diajukan dalam penelitian ini adalah personal cost berpengaruh negatif terhadap niat untuk melakukan tindakan whistleblowing. Berdasarkan hasil analisis dari uji $\mathrm{t}$ pada variabel personal cost, menunjukkan bahwa probabilitas signifikansi untuk variabel personal cost (X2) sebesar 0,628>0,05 dan hasil perhitungan diperoleh angka $t_{\text {hitung }}$ sebesar $0,488<t_{\text {table }}$ sebesar 1,6802. Maka dapat disimpulkan bahwa hipotesis kedua ditolak.

Hipotesis ketiga yang diajukan dalam penelitian ini adalah moral reasoning berpengaruh posotif terhadap niat untuk melakukan tindakan whistleblowing. Berdasarkan hasil dari uji $\mathrm{t}$ pada variabel moral reasoning, menunjukkan bahwa probabilitas signifikansi untuk variabel moral reasoning (X3) sebesar $0,092>0,05$ dan hasil perhitungan diperoleh angka $t_{\text {hitung }}$ sebesar-1.721 $<\mathrm{t}_{\text {table }}$ sebesar 1,6802. Maka dapat disimpulkan bahwa hipotesis ketiga ditolak.

\section{Tabel 4 Ringkasan Pengujian Hipotesis}

\begin{tabular}{|c|c|c|c|}
\hline Model & F & Sig. & Kesimpulan \\
\hline Regression & 11.646 & $0,000^{\mathrm{a}}$ & Diterima \\
\hline
\end{tabular}

Hipotesis keempat yang diajukan dalam penelitian ini adalah Komitmen Profesional, Personal Cost, dan Moral Reasoning secara simultan berpengaruh positif terhadap niat untuk melakukan tindakan Whistleblowing.Berdasarkan hasil dari uji F pada variabel komitmen profesional, personal cost, dan moral reasoning, menunjukkan bahwa probabilitas signifikansi sebesar $0,000<0,05$ dan hasil perhitungan

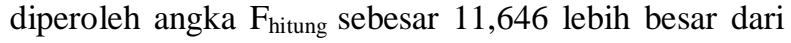
$F_{\text {tabel }}$ sebesar 2,82. Hasil ini menyatakan bahwa hipotesis keempat diterima.

\section{KESIMPULAN}

Penelitian ini bertujuan untuk mengetahui pengaruh komitmen profesional, personal cost, dan moral reasoning terhadap niat untuk melakukan tindakan whistleblowing pada pegawai KPP Pratama Kebumen. Hasil penelitian ini menunjukkan niat untuk melakukan tindakan whistleblowing pegawai KPP Pratama Kebumen di pengaruhi oleh komitmen profesional. Sedangkan personal cost dan moral reasoning tidak berpengaruh terhadap niat untuk melakukan tindakan whistleblowing.

\section{SARAN}

Penelitian ini masih memiliki beberapa keterbatasan, untuk penelitian selanjutnya disarankan untuk menambahkan variabel lainnya diluar variabel yang telah digunakan dalam penelitian ini. Variabelvariabel lain yang mungkin menarik untuk diteliti antara lain status wrong doer, tanggung jawab pelaporan, pertimbangan etis, reward, tingkat keseriusan kesalahan dan lain sebagainya. Disarankan juga bagi penelitian selanjutnya dengan tema yang sama, untuk menggunakan metodologi penelitian dan objek penelitian yang berbeda dan juga memperbanyak jumlah responden dalam penelitian agar dapat dilihat perbedaan dan persamaan antara penelitian ini dan penelitian terbaru.

\section{DAFTAR PUSTAKA}

Association of Certified Fraud Examiner (ACFE). 2012. Report to the Nations on Occupational Fraud and Abuse.

Ahyaruddin, M dan M. Asnawi. 2017. Pengaruh Moral Reasoning dan Ethical Environment Terhadap Kecenderungan Untuk Melakukan Whistleblowing 7(1): 1-20.

Al-Fithrie, N.L. 2015. Pengaruh Moral Reasoning dan Ethical Sensitivity Terhadap Persepsi Etis Mahasiswa Akuntansi Dengan Gender Sebagai Variabel Moderasi. Skripsi. Universitas Negeri Yogyakarta. Yogyakarta.

Astuti, E. K. 2018. Pengaruh Etika, Komitmen Profesional, Sosialisasi Antisipatif, dan Locus of Control Mahasiswa Akuntansi Terhadap Perilaku Whistleblowing. Skripsi. Universitas Islam Indonesia. Yogyakarta.

Brandon. 2013. Whistle Blower. Diakses di http://www.scribd.com/doc/12331853 9/Whistle-Blower. Diakses pada tanggal 24 April 2014.

Cohen, J. R., L. W. Pant, dan D. J. Sharp. 2001. An examination of differences in ethical decision making between Canadian business students and Accounting professionals. Journal of Business Ethics 30(4): 319-336.

Curwen, L. 2003. The Corporate Conscience. https://www.theguardian.com/business /2003/jun/21/corporatefraud.enron. diakses pada 5 Oktober 2018 pukul 13.05 WIB. 
Diani, R.C. dan I.M. Narsa. 2017. Level Penalaran Moral dan Konflik Peran : Studi Eksperimen Bagi Model Perilaku Whistleblowing Aparat Pengawasan Internal Pemerintah. Jurnal Tata Kelola dan Akuntabilitas Keuangan Negara 3(2): 131-149.

Dwyer, P.D., R.B. Welker, dan A.H. Friedberg. 2000. A Research Note Concerning the Dimensionality of the Professional Commitment Scale. Behavioral Research in Accounting Vol. 12.

Ghozali, I. 2016. Aplikasi Analisis Multivariatif dengan Program IBM SPSS 19. Cetakan VIII Badan Penerbit Universitas Diponegoro. Semarang.

Hanif, R.A. dan F. Odiatma. 2017. Pengaruh Lingkungan Etika Terhadap Niat Melakukan Whistleblowing Dengan Locus of Control Sebagai Variabel Moderasi. Jurnal Akuntansi Keuangan dan Bisnis 10(2): 61-69.

Hasanuddin, M.R. 2014. Pengaruh Komitmen Profesional dan Sosialisasi Antisipatif Terhadap Sikap Mahasiswa Akuntansi Atas Akuntabilitas Sosial Perusahaan. SNA XVII Universitas Mataram, 2527 September.

\section{KBBI.2016. Kamus Besar Bahasa Indonesia (Online). Tersedia di http://kbbi.web.id/pusat. Diakses pada 15 Oktober 2018}

Komite Nasional Kebijakan Governance (KNKG). 2006. Pedoman Umum Good Coorporate Governance Indonesia. Jakarta. Diakses tanggal 1 Oktober 2018.

Detiknews. 2013. Kronologi Kasus Susno: l'Cicak vs Buayal' Hingga Korupsi Pilgub Jabar. https://news.detik.com/berita/2229197 /kronologi-kasus-susno-cicak-vsbuaya-hingga-korupsi-pilgub-jabar/1.
Diakses pada 5 Oktober pukul 15.55 WIB.

Kountur, R. 2004. Metode Penelitian : Untuk Penulisan Skripsi dan Tesis. Cetakan Kedua. Penerbit PPM. Yogyakarta

Lestari, R. dan R. Yaya. 2017. Whistleblowing dan Faktor-Faktor yang Mempengaruhi Niat Melaksanakan Oleh Aparatur Sipil Negara. Jurnal Akuntansi 21(03): 336350.

Mahardika, A.S. 2016. Modal Sosial Pada Profesi Akuntan Di Daerah Istimewa Yogyakarta: Kepemimpinan Etis Sebagai Variabel Anteseden Dan Hasil Kerja Sebagai Variabel Konsekuensi. Tesis. Program Studi Magister Sains Ilmu Akuntansi Fakultas Ekonomika Dan Bisnis. Universitas Gadjah Mada. Yogyakarta.

Merdikawati, R. 2012. Hubungan Komitmen Profesional dan Sosialisasi Antisipatif Mahasiswa Akuntansi Dengan Niat Whistleblowing. Skripsi. Universitas Diponegoro. Semarang.

Miceli, M. P. dan J. P. Near. 1995. Characteristics of Organizational Climate and Perceived Wrongdoing Associated with Whistle-Blowing Decisions. Personnel Psychology 38(1985): 525-544.

Nugraha, T. 2017. Pengaruh Komitmen Profesional, Lingkungan Etika, Sifat Machiavellian, dan Personal Cost Terhadap Intensi Whistleblowing Dengan Retaliasi Sebagai Variabel Moderating. JOM Fekon 4(1): 20302044.

Pengesti, S.N. dan S. Rahayu. 2017. Pengaruh Komitmen Profesional dam Sosialisasi Antisipatif Mahasiswa Akuntansi Terhadap Whistleblowing. eProceeding of Management 4(3): 2750-2761. 
Peraturan Kepala Lembaga Pengadaan Barang/Jasa Pemerintah Nomor 7 Tahun 2012 Tentang Whistleblowing Systemdalam Pengadaan Barang/Jasa Pemerintah.

Prasetyo, H. 2016. Pendidikan Anti Korupsi. STIE Putra Bangsa Kebumen. Kebumen

Prastika, N.I. 2017. Komitmen Profesional, Sosialisasi Antisipatif, dan Locus of Control : Pengaruhnya Terhadap Perilaku Whistleblowing. Skripsi. Institut Agama Islam Negeri Surakarta. Surakarta.

Ramadhany, N. F. 2017. Personal Cost dan Efektifitas Whistleblowing System Terhadap Pendeteksian Fraud Dengan Self Efficacy Sebagai Pemoderasi. Skripsi. Universitas Islam Negeri Alauiddin Makasar. Makasar.

Schultz, J.J., D.A. Johnson, D. Morris, dan S. Dyrnes. 1993. An Investigation The Reporting Of Questionable Acts In An International Setting. Journal of Accounting 31 (1): 75-103.

Setyawati, I., K Ardiyani, dan C.R. Sutrisno. 2015. Faktor-Faktor yang Mempengaruhi Niat Untuk Melakukan Whistleblowing Internal. Jurnal Ekonomi dan Bisnis 17(2): 22-33.

Soeratno, L. dan Arsyad. 1999. Metodelogi Penelitian:Untuk Ekonomi dan Bisnis. AMP YKPN. Yogyakarta

Sugiyono. 2006. Metode Penelitian Bisnis. Cetakan Kesembilan. CV Alfabeta. Bandung. . 2009. Metode Penelitian Bisnis : Pendekatan Kuantitatif, Kualitatif dan $R \& D$. Cetakan Ke-14. CV Alfabeta. Bandung
2010. Metode Penelitian Kuantitatif, Kualitatif, dan $R \& D$. Cetakan Ke-11. CV Alfabeta. Bandung.

Tempo.co. 2012. Dirjen Pajak: Whistleblowing System Berjalan Baik.https://nasional.tempo.co/read/4 16988/dirjen-pajak-whistleblowingsystem-berjalan-

baik/full\&view $=$ ok. diakses pada 15 Desember 2018 pukul 10.44 WIB.

Winardi, R.D. 2013. The Influence of Individual and Situational Factors on Lower-Level Civil Servants Whistleblowing Intention in Indonesia. Journal of Indonesian Economy and Business.28(3):361-376. 